\title{
Reduction of Total Harmonic Distortion in Nine level Cascaded Multilevel Inverter with different types of load
}

\author{
Chetanya Gupta $^{1}$, Gajendra Sharma ${ }^{2}$, Abhishek Varshney ${ }^{3}$, Rajneesh Suhalka ${ }^{4}$ \\ ${ }^{1,4}$ (Electrical \& Electronics Engg. Deppt, Assistant Professor, BMIT, Jaipur, Rajasthan, India) \\ ${ }^{2}$ (Maintenance Engineer, Poly Cab Cable \& Wire Pvt. Ltd., Varodara, Gujarat) \\ ${ }_{3}^{3}$ (Power Electronics \& Drives (M.TECH.), Galgotias University, Greater Noida, Uttar Pradesh, India)
}

\begin{abstract}
The use of multilevel inverters have become popular in recent years for high power application. Multilevel inverters are power converter systems composed by an array of power semiconductors sources that when properly connected and controlled can generate a multistep voltage waveform with variable and controllable frequency, phase and amplitude. This study deals a nine level inverter system with different types of loads; the voltage source inverters( VSI ) are modelled and simulated using MATLAB simulink and the result are presented. The test results verify the effectiveness of the proposed strategy in terms of computational efficiency as well as the capability of the inverter to produce very low distorted voltage with low switching losses. This research aims to extend the knowledge about the performance of different clamped multilevel inverter through harmonics analysis. Simulations results validate up to the mark performance of the mentioned topologies.
\end{abstract}

Keywords: Multilevel Inverter, High power applications, Multicarrier Technique, Voltage Source Inverter, Pulse Width Modulation.

\section{Introduction}

Power Electronic Converters, especially DC/AC PWM inverters have been extending their range of use in industry because they provide reduced energy consumption, better system Efficiency, improved quality of product, good maintenance, and so on.

For a medium voltage grid, it is troublesome to connect only one power semiconductor switches directly $[1,2,3]$. As a result, a multilevel power converter structure has been introduced as an alternative in high power and medium voltage situations such as laminators, mills, conveyors, pumps, fans, blowers, compressors, and so on. As a cost effective solution, multilevel converter not only achieves high power ratings, but also enables the use of low power application in renewable energy sources such as photovoltaic, wind, and fuel cells which can be easily interfaced to a multilevel converter system for a high power application.

The most common initial application of multilevel converters has been in traction, both in locomotives and track-side static converters [4]. More recent applications have been for power system converters for VAR compensation and stability enhancement [5], Active Filtering [6], High- Voltage motor drive [3], High-voltage DC transmission [7], and most recently for medium voltage Induction motor variable speed drives [8]. Many multilevel converter applications focus on industrial medium-voltage motor drives [3, 9], utility interface for renewable energy systems [10], Flexible AC transmission system (FACTS) [11], and Traction Drive systems [12].

\section{Cascade Multilevel Inverter}

CHB are multilevel inverters formed by the series connection of two or more single phase H-bridge inverters, hence the name. Each H-Bridge corresponds to two voltage source phase legs where the line- line voltage is converter output. Therefore a single $\mathrm{H}$-Bridge converter is able to generate three different levels. Each leg has only two possible switching states. To avoid dc-link capacitor short circuit since there are two legs, four different switches states are possible, although two of them have reduced output voltage. The zero level can be generated connecting the phase outputs to the positive or the negative bars of the inverter. When two or more Hbridges are connected in series. Their output voltages can be combined to form different levels, increasing the total inverter output and also its rated power. 


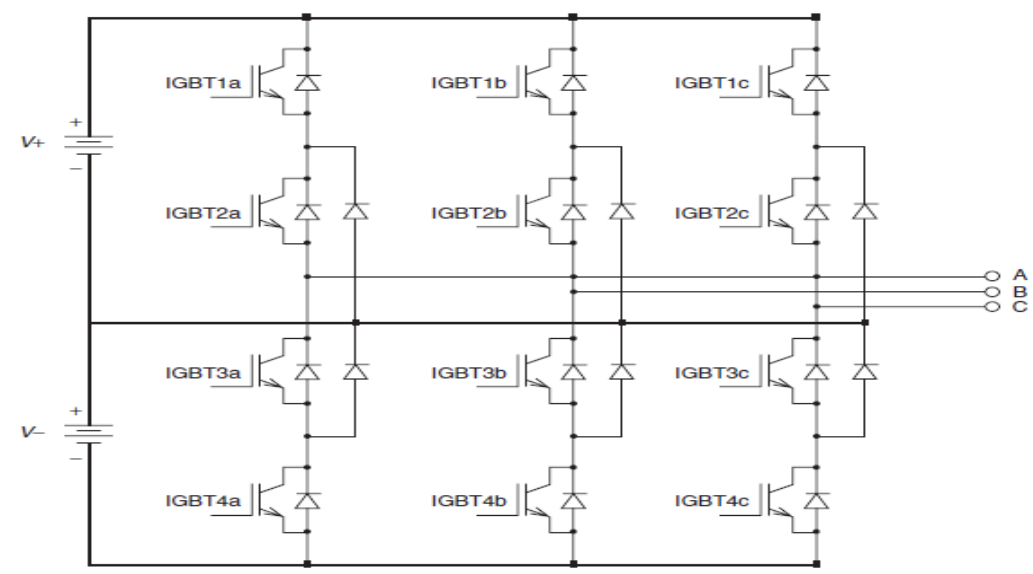

Fig III: Cascade Multilevel Inverter

\section{Methods For Harmonic Reduction In Inverters}

In case of an inverter, it is very important to remove the harmonics from the ac output. The harmonics present in a $\mathrm{DC}$ to $\mathrm{AC}$ inverter are very much obvious compared to the harmonics that can be present in an $\mathrm{AC}$ to dc converter. This is because of the output of DC to AC inverter. Thus, the filters that are used in DC to AC inverter have different designs compared to the filters used in $\mathrm{AC}$ to $\mathrm{DC}$ converters. In case of AC to DC converters, the main objective is to improve the output voltage ripple. Thus, passive filters can be easily used in order to improve the output of an AC to dc converter. While, in case of DC to AC inverter, the harmonic reduction is harder and it also includes the use of active filters. One such technique is explained below.

The ratio of $\mathrm{Vr} / \mathrm{Vc}$ is called Modulation Index (MI) and its control the harmonic contentof the output voltage waveform. The magnitude of fumdamental component of output voltage is proportional to MI, but MI can never be more than unity. Thus the output voltage is controlled by varyiong MI

\section{Multicarrier Pulse Width Modulation}

The most common and popular technique of digital pure-sine wave generation is pulse width modulation. The PWM technique involves generation of a digital waveform, for which the duty cycle is modulated such that the average voltage of the waveform corresponds to a pure sine wave. The simplest way of producing the PWM signal is through comparison of a low-power reference sine wave with a triangle wave. Multicarrier PWM methods uses high switching frequency carrier waves in comparison to the reference waves to generate a sinusoidal output wave. The Figure-5.5 shows multicarrier PWM waveform for cascaded multilevel inverter.

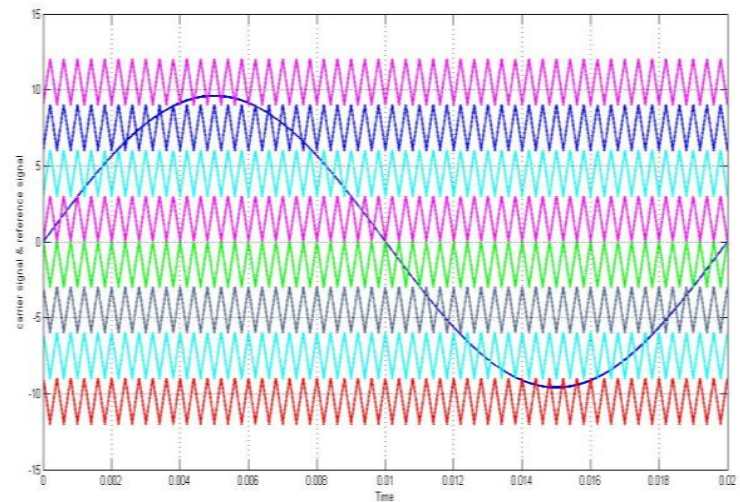

Fig IV: Multi carrier PWM waveform 
V. Matlab Simulink Based Models Of Cascade Multilevel Inverter

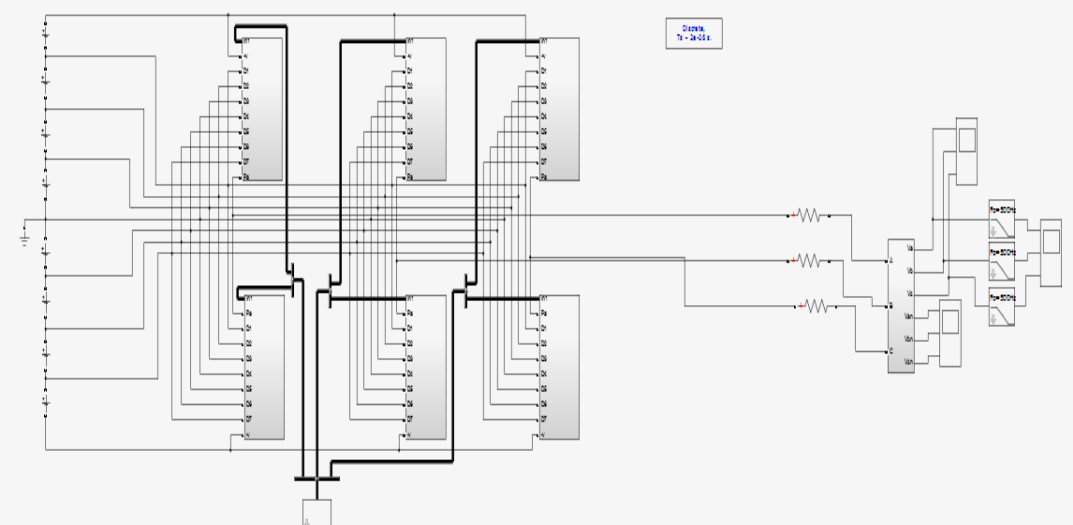

Fig V(A): Nine level with R load

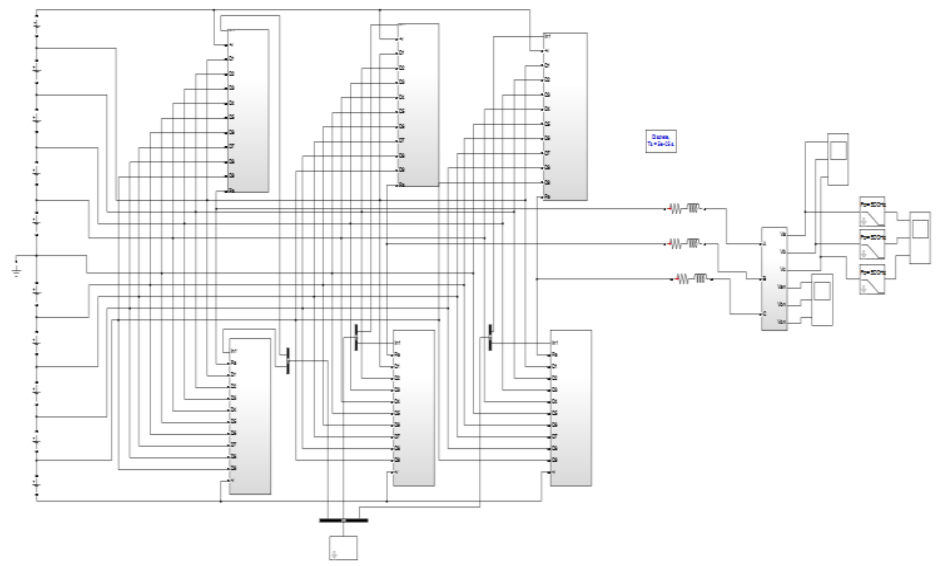

Fig V(B): Nine level with RL load

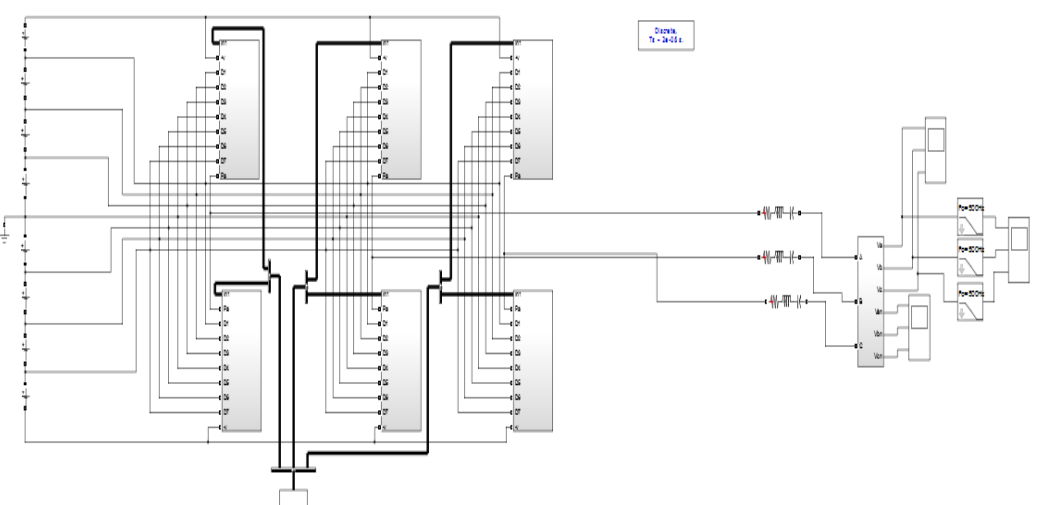

Fig V(C): Nine level with RLC load 


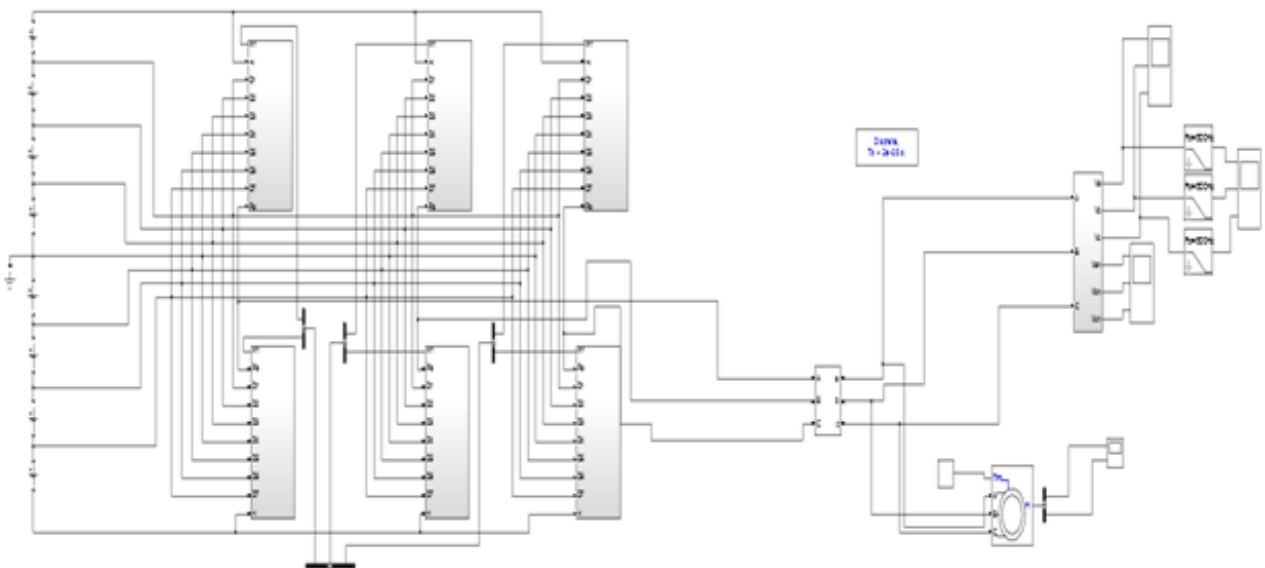

Fig V(D): Nine level with RLE (MOTOR) load

\section{Results And Analysis}
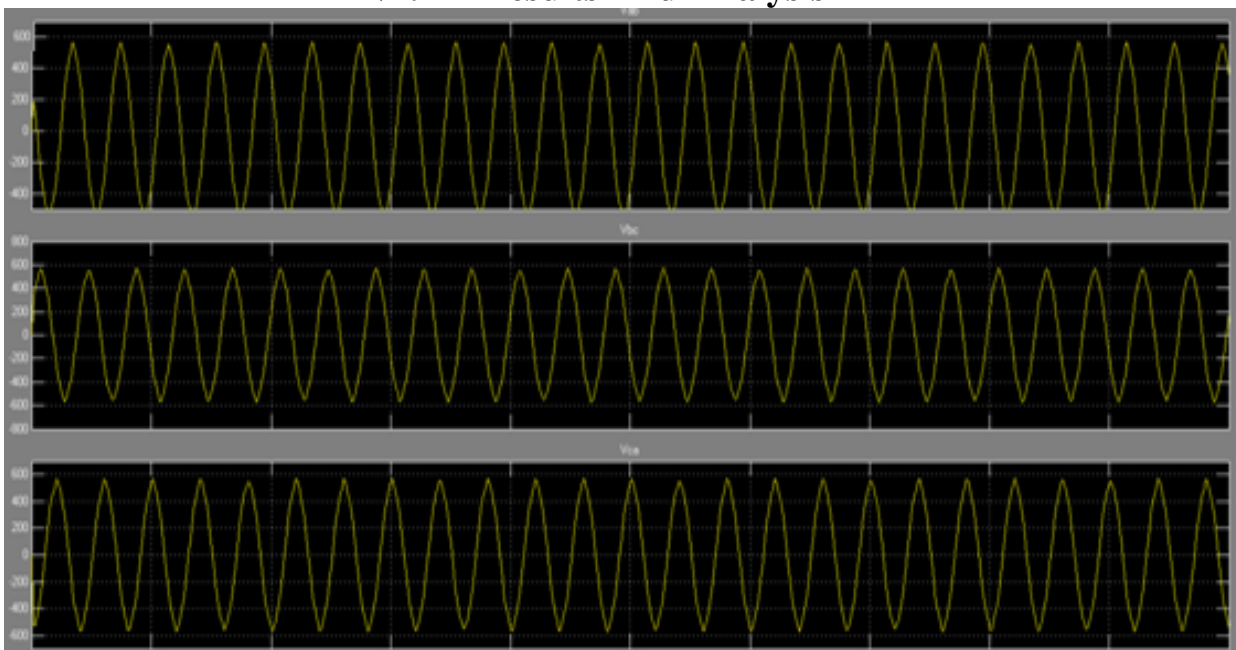

Fig VI(A): Waveforms of R load

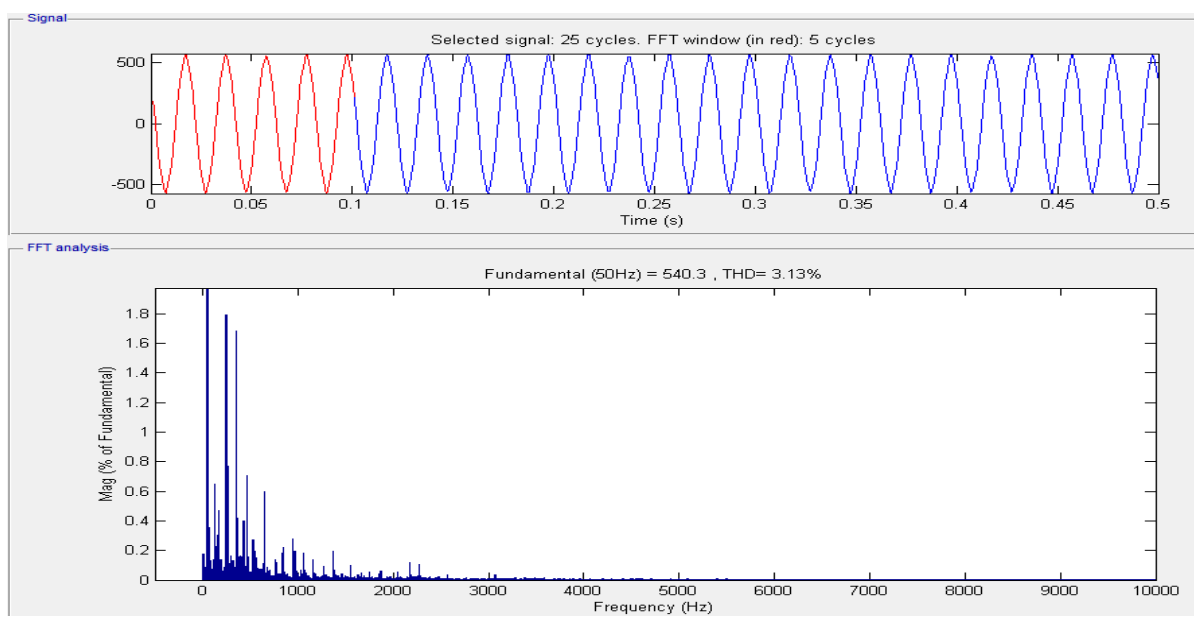

Fig V1(B): THD analysis of R load 


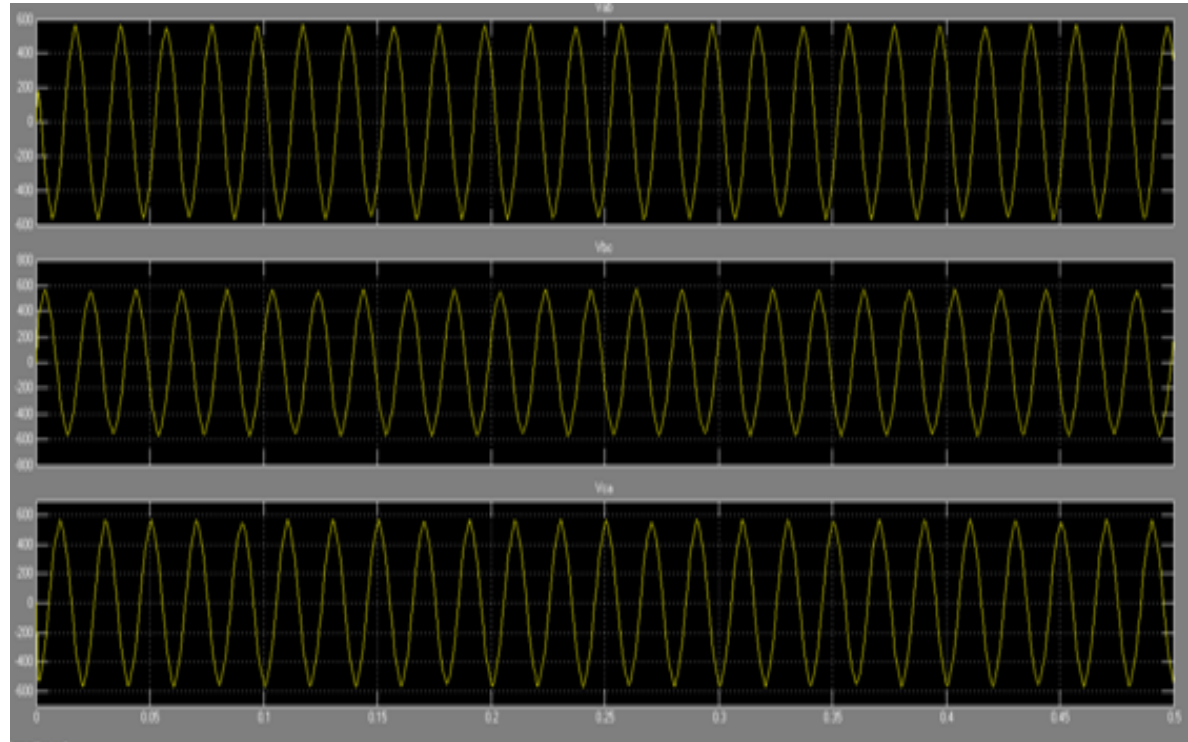

Fig VI(C): Waveforms of RL load
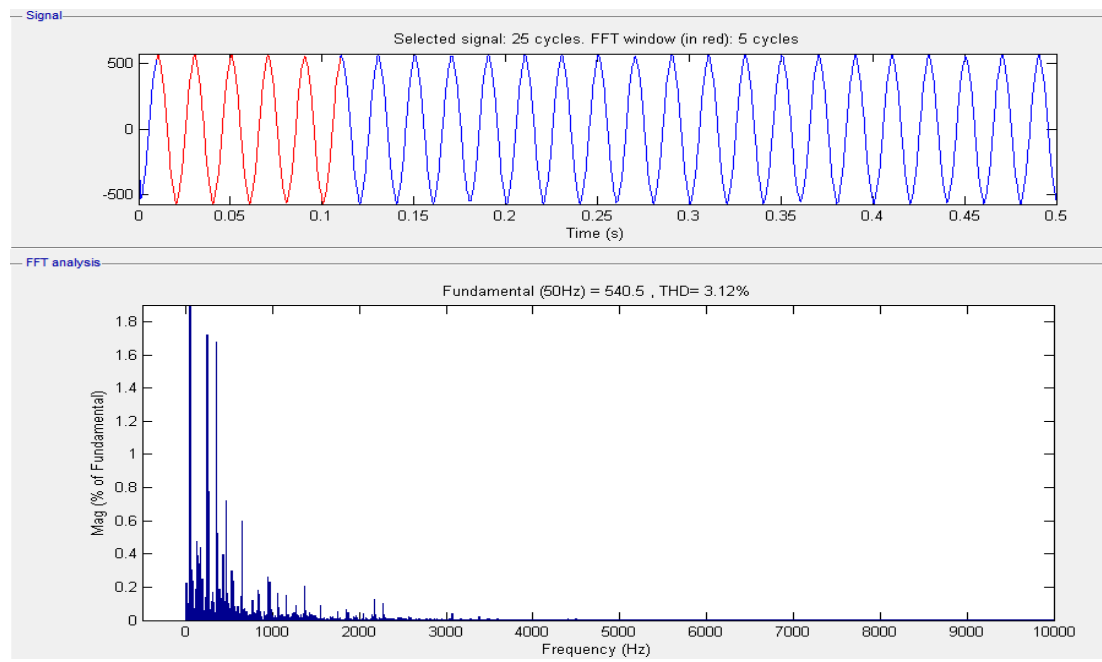

Fig VI(D): THD analysis of RL load

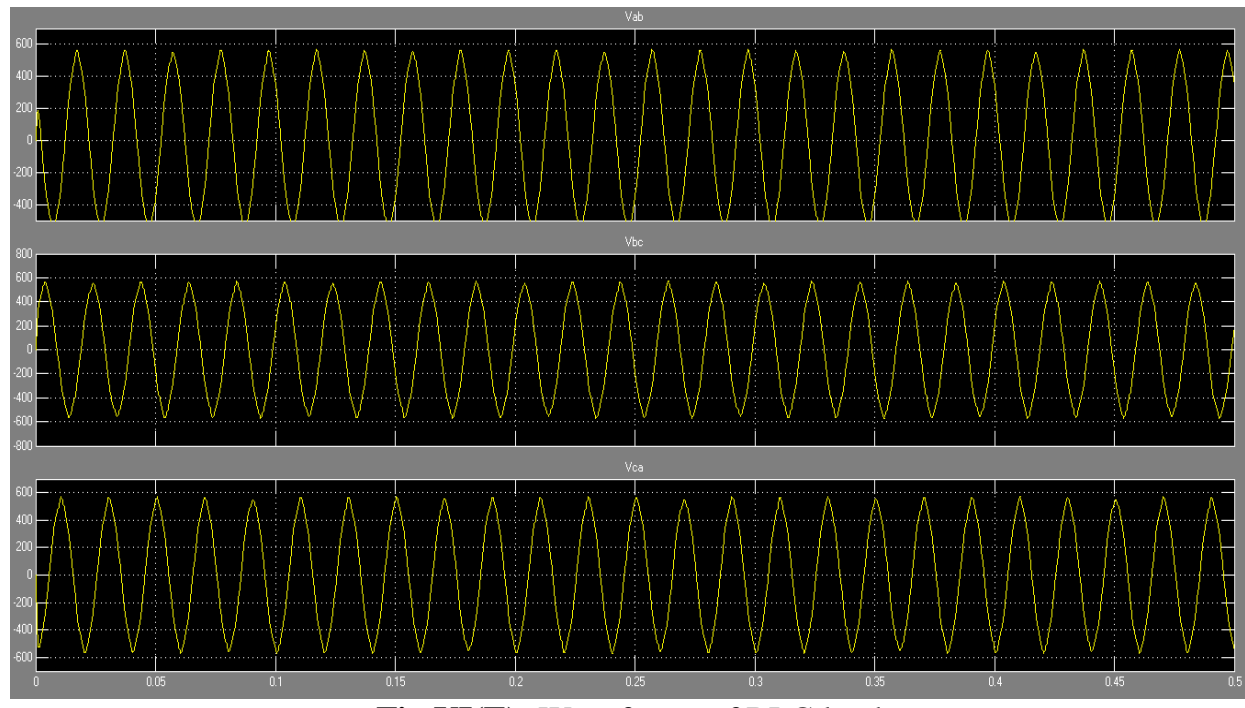

Fig VI(E): Waveforms of RLC load 

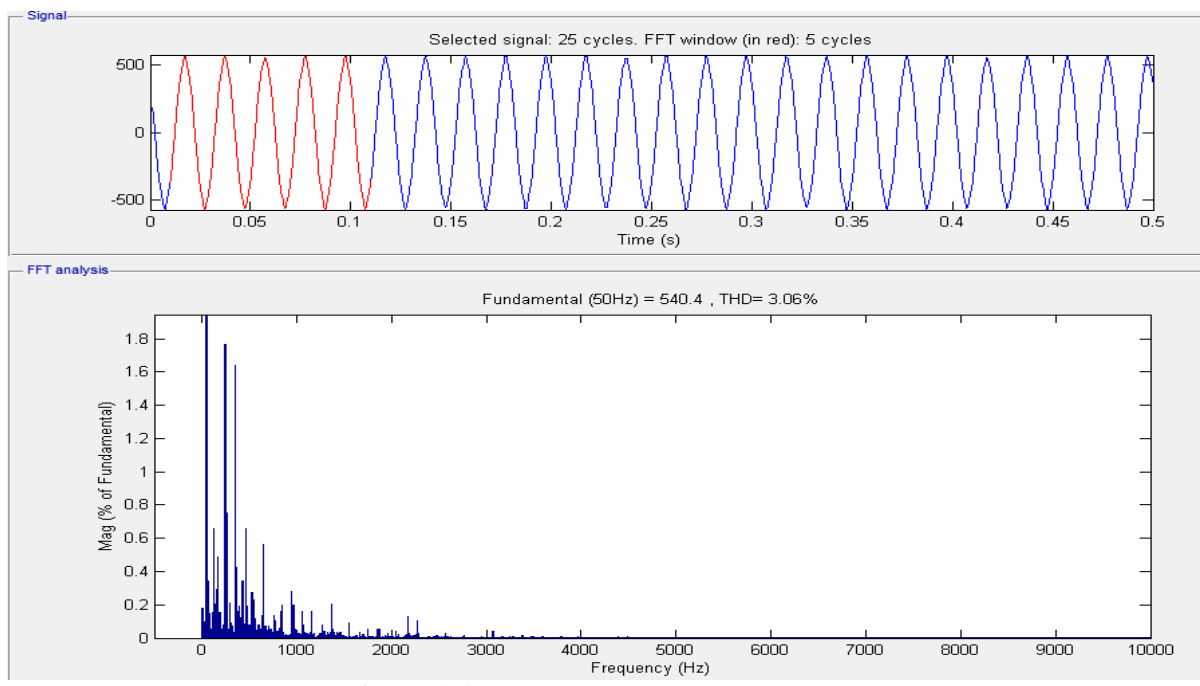

Fig VI(F): THD analysis of RLC load

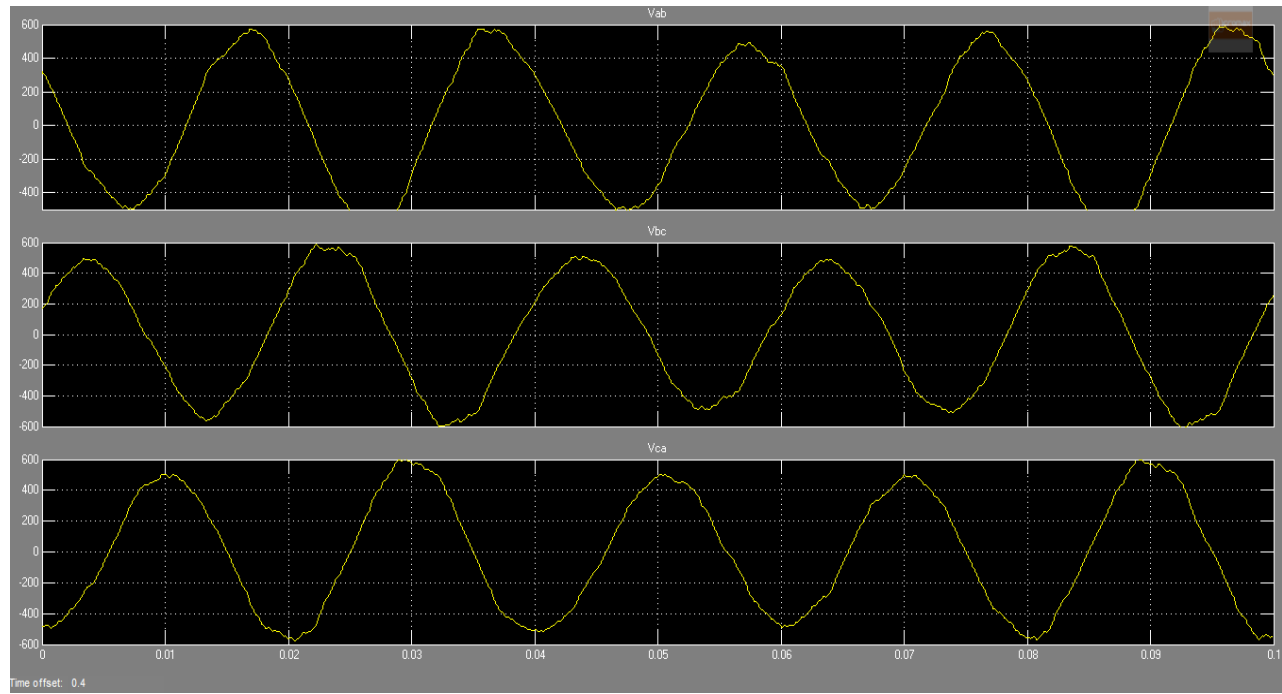

Fig VI(G): waveform of RLE load

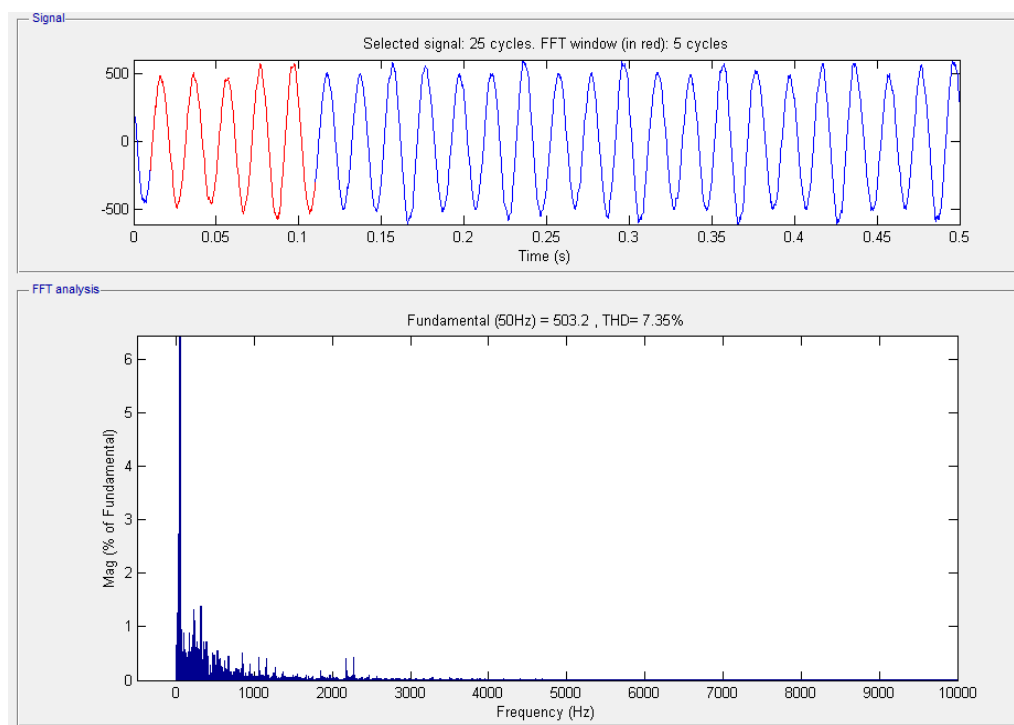

Fig VI(H): THD analysis for nine level with motor in line voltage 1 


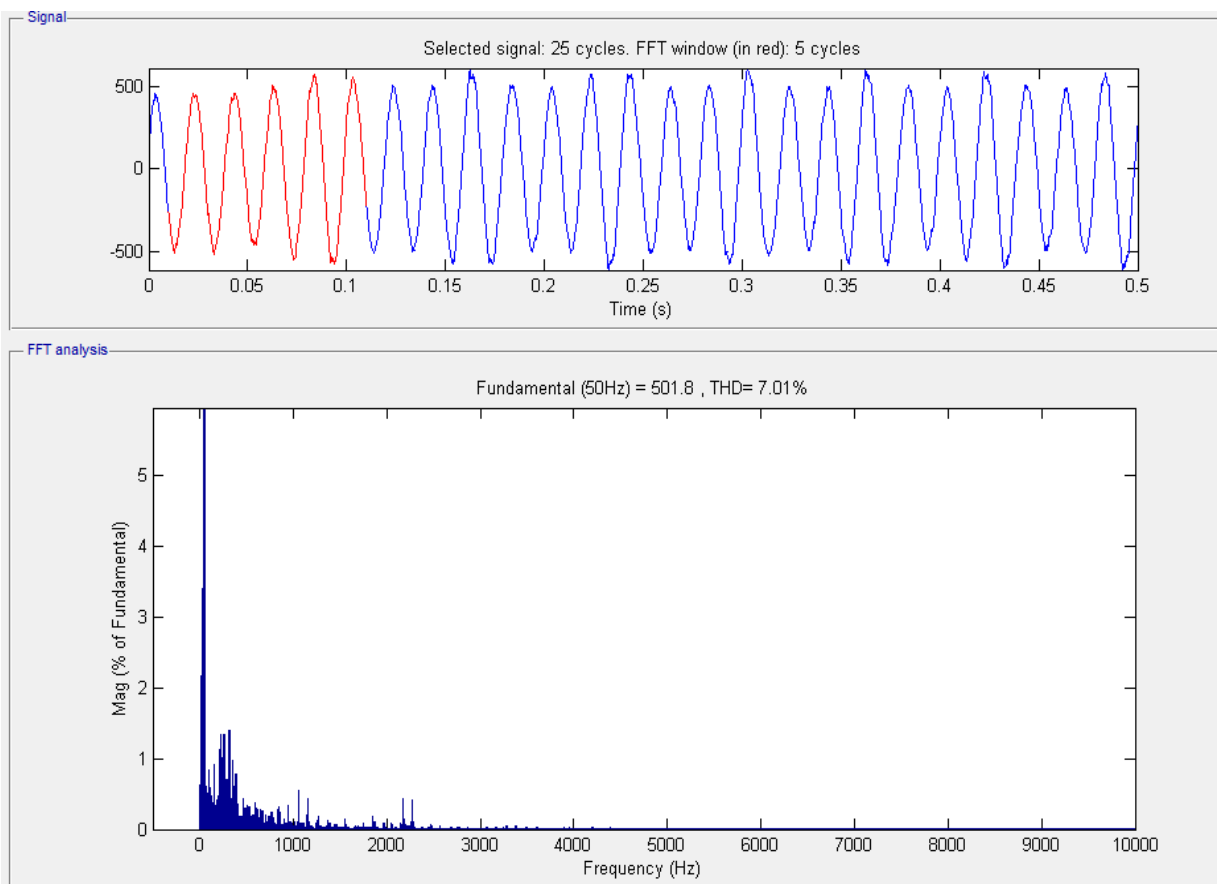

Fig VI(I): THD analysis for nine level with motor in line voltage 2

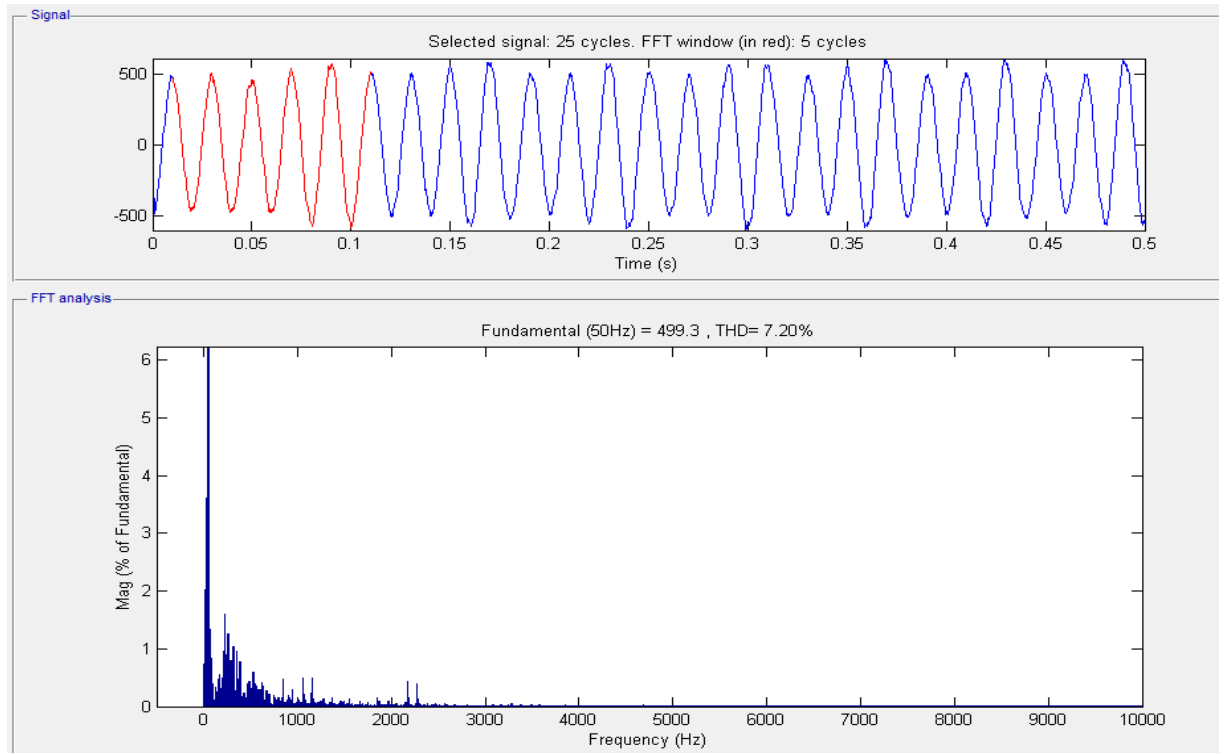

Fig VI(J): THD analysis for nine level with motor in line voltage 3

VII. Table For Parameters

\begin{tabular}{|c|c|}
\hline Voltage & $350 \mathrm{~V}$ (Line to Line) \\
\hline Nominal Power & $3730 \mathrm{~W}$ \\
\hline Frequency & $50 \mathrm{~Hz}$ \\
\hline Pole Pair & 2 \\
\hline Torque & $3 \mathrm{~N}-\mathrm{m}$ \\
\hline Speed & $1500 \mathrm{Rev} / \mathrm{min}$ \\
\hline Rotation inertia & $0 . .02 \mathrm{Kg}-\mathrm{m}^{2}$ \\
\hline Stator Resistance $\left(\mathrm{R}_{\mathrm{s}}\right)$ & $1.115 \Omega$ \\
\hline Rotor Resistance $\left(\mathrm{R}_{\mathrm{r}}\right)$ & $1.083 \Omega$ \\
\hline Stator Inductance $\left(\mathrm{L}_{\mathrm{s}}\right)$ & $0.005974 \mathrm{H}$ \\
\hline Rotor Inductance $\left(\mathrm{L}_{\mathrm{r}}\right)$ & $0.005974 \mathrm{H}$ \\
\hline Mutual Inductance $\left(\mathrm{L}_{\mathrm{m}}\right)$ & $0.2037 \mathrm{H}$ \\
\hline
\end{tabular}




\section{Summary Of Results}

\begin{tabular}{|c|c|}
\hline Loads & Nine Levels MLI THD (\%) \\
\hline R & 3.13 \\
\hline RL & 3.12 \\
\hline RLC & 3.06 \\
\hline Motor (RLE load) & Nine Levels MLI THD (\%) \\
\hline Line voltage 1 & 7.35 \\
\hline Line voltage 2 & 7.01 \\
\hline Line voltage 3 & \\
\hline
\end{tabular}

\section{Conclusions}

In this research paper, the nine level multilevel H-bridge inverter is briefly discussed. And an implementation is done in MATLAB/SIMULINK software tool. From the analysis, nine level multilevel inverters is the best suited topology for the dc to ac conversion. Multi carrier PWM modulation technique is best technique, which gives low total harmonic distortion (THD).

\section{Acknowledgements}

Sincere gratitude is hereby extended to those who never ceased in helping until this paper is structured. The authors will be highly obliged the unwavering moral,emotional and financial support of our family members and friends, Above all, Utmost appreciation to the almighty God for the divine intervention in the academic endeavor.

\section{References}

[1]. J. S. Lai and F. Z. Peng, "Multilevel converters - A new breed of power converters," IEEE Trans. Ind. Applicant., vol. 32, pp. 1098-1107, May/June 1996.

[2]. J. Rodriguez, J.-S. Lai, and F. Z. Peng, "Multilevel inverters: a survey of topologies, controls, and applications," IEEE Trans. Ind. Electron., vol. 49, pp. 724-738, 2002. [3] L. M. Tolbert, F. Z. Peng, and T. G. Habetler, "Multilevel converters for large electric drives," IEEE Trans. Ind. Applicat., vol. 35, pp. 36-44, 1999.

[3]. H. Stemmler. Power electronics in electric traction applications. IEEE conference of Industrial Electronics, Control and Instrumentation, IECON'93, 2:7 07 - 713, 1993.

[4]. H. Fujita, S. Tominaga, and H. Akagi. Analysis and design of an advanced static VAR compensator using quad-series voltagesource inverters. IEEE Industry Apps Meeting, 3:2565-2572, 1995

[5]. Y. Yoshioka, S. Konishi, N. Eguchi, M. Yamamoto, K. Endo, K. Maruyama, and K. Hino. Self-commutated static flicker compensator for arc furnaces. In IEEE Applied Power Electronics Conference, volume 2, pages 891-897, 1996.

[6]. L. Gyugyi, "Power electronics in electric utilities: static var compensators." Proc. IEEE, vol. 76, pp. 3, 1987.

[7]. Peter W. Hammond. A new approach to enhance power quality for medium voltage AC drives. IEEE Trans. Industry Applications, 33(1):202-208, January 1997.

[8]. M. F. Escalante, J. C. Vannier, and A. Arzande "Flying Capacitor Multilevel Inverters and DTC Motor Drive Applications," IEEE Transactions on Industry Electronics, vol. 49, no. 4, Aug. 2002, pp. 809-815.

[9]. L. M. Tolbert, F. Z. Peng, "Multilevel Converters as a Utility Interface for Renewable Energy Systems," in Proceedings of 2000 IEEE Power Engineering Society Summer Meeting, pp. 1271-1274.

[10]. L. M. Tolbert, F. Z. Peng, T. G. Habetler, "A Multilevel Converter-Based Universal Power Conditioner," IEEE Transactions on Industry Applications, vol. 36, no. 2, Mar./Apr. 2000 pp.596-603.

[11]. L. M. Tolbert, F. Z. Peng, T. G. Habetler, "Multilevel Inverters for Electric Vehicle Applications," IEEE Workshop on Power Electronics in Transportation, Oct 22-23, 1998, Dearborn, Michigan, pp. 1424-1431. [13] In-Dong Kim, Eui-Cheol Nho,, HeungGeun Kim, , and Jong Sun Ko,. 'A Generalized Undelan Snubber for Flying Capacitor Multilevel Inverter and Converter'. IEEE transactions on industrial electronics, vol. 51, no. 6, December 2004.

[12]. By Jose' Rodrı'guez, Senior Member IEEE, Leopoldo G. Franquelo, Fellow IEEE, Samir Kouro, Member IEEE, Jose' I. Leo'n, Member IEEE, Ramo'n C. Portillo, Student Member IEEE, Ma A'ngeles Martı'n Prats, Member IEEE, and Marcelo A. Pe'rez, Member IEEE Vol. 97, No. 11, November 2009.

[13]. J. S. Lai and F. Z. Peng, BMultilevel converters. A new breed of power converters,[ IEEE Trans. Ind. Appl., vol. 32, pp. 509-517, May/Jun. 1996.

[14]. J. Rodri'guez, B. Wu, S. Bernet, J. Pontt, and S. Kouro, BMultilevel voltage source converter topologies for industrial medium voltage drives, [ IEEE Trans. Ind. Electron. (Special Section on High Power Drives), vol. 54, pp. 2930-2945, Dec. 2007.

[15]. T. Bruckner, S. Bernet, and H. Guldner, BThe active NPC converter and its lossbalancing control,[ IEEE Trans. Ind. Electron., vol. 52, pp. 855-868, Jun. 2005.

[16]. R. H. Baker and L. H. Bannister, "Electric Power Converter,” U.S. Patent 3867 643, Feb. 1975.

[17]. T. A. Meynard and H. Foch, "Multilevel conversion: High voltage choppers and voltage source inverters," in Proc. IEEE PESC'92, 1992, pp. 397-403.

[18]. F. Z. Peng, J-S Lai, "Multilevel Converters - A New Breed of Power Converters,"IEEE Transactions on Industry Applications, Vol.32, No.3, May/June, 1996, pp.509-517.

[19]. S. Ceballos, J. Pou, I. Gabiola, J. Villate, J. Zaragoza, and D. Boroyevich, BFault-tolerant multilevel converter topology,[ in Proc. 2006 IEEE Int. Symp. Ind. Electron., Jul. 2006, vol. 2, pp. 1577-1582.

[20]. J. Rodrı'guez, J. Pontt, G. Alzamora, N. Becker, O. Einenkel, and A. Weinstein, BNovel 20 MW downhill conveyor system using three-level converters, [ IEEE Trans. Ind. Electron., vol. 49, pp. 1093-1100, Oct. 2002.

[21]. A. Nabae, I. Takahashi, and H. Akagi, BA neutral-point clamped PWM inverter,[ IEEE Trans. Ind. Appl., vol. IA-17, pp. 518-523, Sep./Oct. 1981.

[22]. T. A. Meynard and H. Foch, BElectronic device for electrical energy conversion between a voltage source and a current source by means of controllable switching cells, [ IEEE Trans. Ind. Electron., vol. 49, pp. 955-964, Oct. 2002. 
[23]. P. Hammond, BA new approach to enhance power quality for medium voltage drives,[IEEE Trans. Ind. Appl., vol. 33, no. 1, pp. 202-208, 1997.

[24]. G. Carrara, S. Gardella, M. Marchesoni, R. Salutari, and G. Sciutto, BA new multilevel PWM method: A theoretical analysis,[ IEEE Trans. Power Electron., vol. 7, pp. 497-505, Jul. 1992.

[25]. G. Holmes and T. Lipo, Pulse Width Modulation for Power Converters. New York: IEEE Press/Wiley, 2003.

[26]. D. Zhong, L. M. Tolbert, J. N. Chiasson, B. Ozpineci, L. Hui, and A. Q. Huang, BHybrid cascaded H bridges multilevel motor drive control for electric vehicles, [ in Proc. 37th IEEE Power Electron. Spec. Conf. (PESC '06), Jun. 18-22, 2006.

[27]. J. Rodri'guez, L. Moran, P. Correa, and C. Silva, BA vector control technique for medium voltage multilevel inverters,[ IEEE Trans. Ind. Electron., vol. 49, pp. 882-888, Aug. 2002.

[28]. S. Kouro, R. Bernal, H. Miranda, C. Silva, and J. Rodr1'guez, B High-performance torque and flux control for multilevel inverter fed induction motors, [ IEEE Trans. Power Electron., vol. 22, pp. 2116-2123, Nov. 2007.

[29]. M. Pe'rez, J. Rodrı'guez, J. Pontt, and S. Kouro, BPower distribution in hybrid multicell converter with nearest level modulation,[ in Proc. IEEE Int. Symp. Ind. Electron. (ISIE 2007), Vigo, Spain, Jun. 4-7, 2007, pp. 736-741. 